\title{
STABILITY ANALYSIS AND GENOTYPE X ENVIRONMENT INTERACTION FOR GRAIN YIELD IN BREAD WHEAT
}

\author{
(Received:28.9.2011) \\ By \\ R. M. Koumber, E. F. El-Hashash* and S. A. Seleem \\ Wheat Research Department, Field Crops Research Institute, Agriculture Research Center and
*Agronomy Department, Faculty of Agriculture, Al-Azhar University, Cairo, Egypt.
}

\begin{abstract}
The objective of this study was to determine stability and genotype $\mathrm{X}$ environment interaction of some wheat genotypes, and the effect of different environments on grain yield to understand their adaptation to varying environments. Forty wheat genotypes were evaluated at three locations (Gemmieza, Nubaria and Mallawy) in Egypt during 2008/2009 and 2009/2010 seasons. Genotypes generally showed variation in their response to changing environment. Combined analysis of variance revealed highly significant variances $(P<0.01)$ due to genotypes $(\mathrm{G})$, locations $(\mathrm{L})$, years $(\mathrm{Y})$, the first order interactions $(\mathrm{G} \times \mathrm{L}, \mathrm{G} \times \mathrm{Y}$ and $\mathrm{Y} \times \mathrm{L})$ and the second order interaction $(\mathrm{G} \times \mathrm{L} \times \mathrm{Y})$ for grain yield. Maximum grain yield was produced in Gemmieza followed by Mallawy and Nubaria locations. Pooled analysis of variance and stability analysis were performed. The variances due to genotypes $(\mathrm{G})$, environments $(\mathrm{E}), \mathrm{E}$ $+(\mathrm{G} \times \mathrm{E}), \mathrm{G} \times \mathrm{E}, \mathrm{E}$ (linear), G x E (linear) and pooled deviation were highly significant $(P<0.01)$. The partitioning of $\mathrm{G} \times \mathrm{E}$ interaction variance into linear and non-linear components indicated that both predictable and unpredictable components shared the interaction. Wide range of stability statistics was observed among genotypes for all the stability parameters. Maximum grain yield of 21.16 (ardab/feddan) was produced by the promising line 32 followed by the promising 33, 28, 23, Sakha 93 and Gemmieza 9. The large variation in mean grain yield, phenotypic variance $\left(\sigma_{\mathrm{P}}^{2}\right)$, coefficient of variation (C.V. \%), regression coefficient (bi) and deviation from regression $\left(\mathrm{S}_{\mathrm{d}}{ }_{\mathrm{d}}\right)$ indicates different responses of genotypes to environmental changes. Genotypes Sakha 93 and the promising lines 23, 31 and 32 showed high grain yield, low deviation from regression and their regression coefficient values were close to unity and could be classified as stable genotypes. Stable performance was expressed by the promising line 32 (Gemmieza 9 / Sids 8 ) because of higher grain yield ( $\bar{x}=21.16$ ardab/feddan), regression coefficient close to unity ( $b_{\mathrm{i}}$ $=1.06)$ and low deviation from regression $\left(\mathrm{S}_{\mathrm{d}}{ }=-0.53\right)$. Regression coefficient of each genotype was highly significant positive correlated with mean, phenotypic variance and coefficient of variation. However, the phenotypic variance had significant and highly significant positive correlation with mean and coefficient of variation, respectively.
\end{abstract}

Key words: correlation, genotype x environment interaction, grain yield, stability parameters, wheat.

\section{INTRODUCTION}

Wheat (Triticum aestivum L.) is the leading human food crop in Egypt. The total national consumption from wheat was about 13 million tons whereas; the national wheat production was about 8 million tons during the last five years. Increasing total wheat grain production is a national goal to meat the increase in wheat consumption resulted from increasing population. The total wheat production could be increased, horizontally, by extending wheat area to the new cultivated land and vertically, via growing high yielding cultivars and supplementing the recommended cultural practices. However, stable wheat cultivars that are tolerant to different environmental stresses are the ultimate goal of the national wheat research program. The environmental effect along with genotype $\mathrm{X}$ environment interaction (GEI) make it difficult to verify and give general recommendations for a particular variety. However, several attempts have been made to specify, estimate and correct GEI. The ideal wheat genotype should be high yielding under different environmental conditions, but as genetic effects are not independent of environmental effects, most genotypes do not 
perform satisfactorily in all environments (Carvalho et al., 1983). When interaction between genotype and environment occurs, the relative ranking of cultivars for yield often differs when genotypes are compared across a series of environments and/or years. This poses a serious problem for selecting genotypes significantly superior in grain yield (Stafford, 1982). GEI are of major importance, because they provide information about the effect of different environments on cultivar performance and have a key role for assessment of performance stability of the breeding materials (Moldovan et al., 2000). Stable genotypes have the same reactions across the environments. Most favourable stability occurs with high yield or performance (Björnsson, 2002). Increasing genetic gains in yield is possible in part from narrowing the adaptation of cultivars, thus maximizing yield in particular areas by exploiting GEI. The genotypes response to environment is multivariate, yet the parametric approach tries to transform it to univariate problem via stability characters. This represents shifts from ranking stability by a quantitative measure to assigning genotypes into qualitatively homogeneous stability subset (Lin et al., 1986). The stability was defined as adaptation of varieties to unpredictable and transient environmental conditions and the technique has been used to select stable genotypes unaffected by environmental changes (Allard and Bradshaw, 1964). Various statistical techniques have been developed to identify systematic variation in individual genotypic responses. Among these, Eberhart and Russell (1966) model has been widely used in studies of adaptability and stability of plant materials. Therefore, the choice of an adequate model to measure the stability of different genotypes is a question to be resolved by researchers. The regression coefficient $\left(b_{i}\right)$ and the average departure from regression line $\left(\mathrm{S}_{\mathrm{d}}^{2}\right)$ are two mathematical indices for the assessment of stability (Eberhart and Russell, 1966). A genotype with a high bi and $S^{2}$ reacts readily to changes in the environment and possesses considerable variability, whereas cultivars with a bi $<1.0$ and $\mathrm{S}_{\mathrm{d}}{ }_{\mathrm{d}}$ near to 0.00 react weakly to changes in growing conditions and are considered to be stable in yield (Shindin and Lokteva, 2000). Finlay and Wilkinson (1963) regarded those genotypes with a $b_{i}$ near 1.0 and high mean yield as being well adapted to all environments. The objectives of this study were to evaluate grain yield magnitude and stability; find quality differences between the genotypes and years; find influence of environment and genotype; identify most stable genotypes and locations; grouping of the genotypes by quality and finding out correlations between the stability parameters.

\section{MATERIALS AND METHODS \\ 2.1. Plant material and environments}

Six field experiments were carried out during $2008 / 2009$ and 2009/2010 growing seasons. The experiments were evaluated at three different locations in Egypt (El-Gemmieza, Nubaria and Mallawy). Forty wheat genotypes (Table 1) were grown in a randomized complete block design with three replications at six environments (3 locations $\mathrm{X} 2$ years). The experimental plot consisted of 6 rows, $4 \mathrm{~m}$. long and $20 \mathrm{~cm}$. width and distance between plants within row was $10 \mathrm{~cm}$ with two plants per hill. Grain yield was obtained from the three interior rows in each plot. Plots were hand harvested, then grains were cleaned and weighed to determine grain yield.

\subsection{Statistical analyses}

Stability parameters were estimated by the method described by Eberhart and Russell (1966). Analysis of variance procedure was adopted to test the significance of location, year, genotype, and first and second order interactions assuming the year and location effects as random and genotype effect as fixed (Comstock and Moll, 1963).

The stability analysis of variance and stability parameters: phenotypic variance, coefficient of variation $(\mathrm{CV} \%)$, linear regression coefficient $\left(\mathrm{b}_{\mathrm{i}}\right)$ and deviation from regression $\left(\mathrm{S}_{\mathrm{d}}{ }_{\mathrm{d}}\right)$ of genotype means across environments index were computed as suggested by Eberhart and Russell (1966). For the regression analysis of variance, the residuals from the combined analysis of variance were used as a pooled error to test the $\mathrm{S}_{\mathrm{d}}{ }_{\mathrm{d}}$ values. A significant $F$ value would indicate that the $S^{2}{ }_{d}$ was significantly different from zero. The hypothesis that each regression coefficient equaled unity was tested by $\mathrm{t}$ test using the standard error of the corresponding $b$ value. Correlation analysis was used to study the relationship between mean yield per se and stability parameters, as well as between studied stability parameters. Correlation coefficients were compared against table r-values given by Fisher and Yates (1953) at (n-2) degrees of freedom at the probability levels of 0.05 and 0.01 to test their significance.

\subsection{Combined analysis}

\section{RESULTS AND DISCUSSION}

The values of variances for genotype, location, year, and their interactions are presented 
Table (1): Pedigree of the forty bread wheat genotypes under six environments.

\begin{tabular}{|c|c|c|}
\hline No. & Cultivar / Line & Pedigree \\
\hline 1 & Sakha 93 & SAKHA 92/TR810328 S8871-IS-2S-IS-0S \\
\hline 2 & Sakha 94 & $\begin{array}{l}\text { OPATA/RAYON//KAUZ.CMBW 90Y3180-OTOM-3Y-010M- } \\
\text { 010Y-10M-015Y-0Y-0AP-0S. }\end{array}$ \\
\hline 3 & Giza 168 & MRL/BUC//SERICM 93046-8 M-OY-OM-2Y-OB-OGZ. \\
\hline 4 & Sids 1 & HD2172/2/PAVON//1158.57/MAYA74SD46 -45D-15D-05D \\
\hline 5 & Gemmieza 7 & $\begin{array}{l}\text { CMH74A.630/SX//SERI82/AGENTCGM 4611-2GM-3GM- } \\
\text { 1GM-OGM }\end{array}$ \\
\hline 6 & Gemmieza 9 & Ald“s”/HUAC//CMH74 .630/SxCGM 4583 -5GM- 1GM- OGM \\
\hline 7 & Gemmieza 10 & $\begin{array}{l}\text { MAYA74 "S" / On // 1160-147BB/ GALL141CHAT"S" } 151 \\
\text { CROW"S". }\end{array}$ \\
\hline 8 & Promising line 1 & GEMMIEZA 27 / MILAN \\
\hline 9 & Promising line 2 & PREW / SAKHA 93 \\
\hline 10 & Promising line 3 & SIDS 7/ MILAN \\
\hline 11 & Promising line 4 & GIZA 168/ SIDS 7 \\
\hline 12 & Promising line 5 & GIZA 168 / GEMMIEZA 7 \\
\hline 13 & Promising line 6 & GIZA168/CHIL//SLMI 75 \\
\hline 14 & Promising line 7 & GHZA168/MAYA//NAC \\
\hline 15 & Promising line 8 & GEMMIEZA9/SIDS 6 \\
\hline 16 & Promising line 9 & GEMMIEZA9/SIDS 4 \\
\hline 17 & Promising line 10 & BUC"S"/DOVE"S"//TSI/3/GEMMIEZA 9 \\
\hline 18 & Promising line 11 & KAUZ*/YACO//KAUZ/3/GEMMIEZA 7 \\
\hline 19 & Promising line 12 & PARENTSK-47-A-1/SAKHA 61 \\
\hline 20 & Promising line 13 & IRENA/WEAVER//GEM. 5 \\
\hline 21 & Promising line 14 & ASKHA206/GEM.LINE 27 \\
\hline 22 & Promising line 15 & KAUKO/CMH82-493//GEM 7 \\
\hline 23 & Promising line 16 & KAUKO/CMH82-493//GEM 9 \\
\hline 24 & Promising line 17 & KAUKO/CMH82-493//GEM 10 \\
\hline 25 & Promising line 18 & KAUKO/CMH82-493//GEM 5 \\
\hline 26 & Promising line 19 & KAUKO/CMH82-493//GEM 3 \\
\hline 27 & Promising line 20 & GIZA168/SAKHA 61 \\
\hline 28 & Promising line 21 & GIZA168/SIDS 6 \\
\hline 29 & Promising line 22 & GIZA168/GEM.3 \\
\hline 30 & Promising line 23 & GIZA168/GEM.10 \\
\hline 31 & Promising line 24 & GIZA168/GEM.7 \\
\hline 32 & Promising line 25 & GIZA168/CHIL//SLM 175 \\
\hline 33 & Promising line 26 & SAKHA 61/SIDS 6 \\
\hline 34 & Promising line 27 & SAKHA 93/SIDS 4 \\
\hline 35 & Promising line 28 & SAKHA 61/GIZA164//SAKHA 61 \\
\hline 36 & Promising line 29 & SAKHA 61/GIZA164//SAKHA 69 \\
\hline 37 & Promising line 30 & GEMMIEZA 7/GEMMIEZA 9 \\
\hline 38 & Promising line 31 & GEMMIEZA 9/SIDS 6 \\
\hline 39 & Promising line 32 & GEMMIEZA 9/SIDS 8 \\
\hline 40 & Promising line 33 & GEMMIEZA 9/SIDS 1 \\
\hline
\end{tabular}

in Table (2). The mean squares due to genotypes $(\mathrm{G})$, locations (L), years $(\mathrm{Y})$, the first order interactions ( $\mathrm{G} \times \mathrm{L}, \mathrm{G} \times \mathrm{Y}$ and $\mathrm{Y} \times \mathrm{L})$ and the second order interaction $(\mathrm{G} \times \mathrm{L} \times \mathrm{Y})$ were highly significant $(P<0.01)$ for grain yield. However, the mean squares due to replications $(\mathrm{Y} \times \mathrm{L})$ were not significant for grain yield. These results indicated that the studied genotypes responded differently to the various environmental conditions, suggesting the importance of the assessment of genotypes under different environments in order to identify the best genetic make up for a particular environment. The presence of GEI indicates that particular genotypes tended to rank differently in grain yields at different locations, while the small GEI 
Table (2): Combined analysis of variance for grain yield based on two year data from three locations in Egypt.

\begin{tabular}{|l|c|c|}
\hline \multicolumn{1}{|c|}{ S.O.V } & d.f & Mean Squares \\
\hline Years (Y) & 1 & $662.78^{* *}$ \\
\hline Locations (L) & 2 & $3930.82^{* *}$ \\
\hline Y x L & 2 & $98.90^{* *}$ \\
\hline Replications (YxL) & 12 & $4.41^{\mathrm{NS}}$ \\
\hline Genotypes (G) & 39 & $49.17^{* *}$ \\
\hline G x Y & 39 & $5.50^{* *}$ \\
\hline G x L & 78 & $22.02^{* *}$ \\
\hline G x L x Y & 78 & $4.91^{* *}$ \\
\hline Error & 468 & 2.93 \\
\hline
\end{tabular}

$*$, ** = Significant at 5 and $1 \%$ probability level, respectively.

NS = Not-Significant.

indicates a small effect of the years on relative productivity.

The significance of variances due to genotypes, environments and their interactions was attributed to variations in different climatic and edaphic conditions at different locations, indicating the necessity of testing at multiple locations over time for accurate characterization of genotypic performance across divergent regions (Afzal Arain, et al., 2001). Ülker et al. (2006) reported that, the results indicated that there were significant variances due to interactions among genotypes, locations and years. Khan et al. (2007) mentioned that, the GEI mean squares were highly significant for grain yield. Combined analysis of variance revealed significant differences among locations, years, genotype $\mathrm{x}$ year and location $\mathrm{x}$ year interactions for grain yield (Parveen et al., 2010). Hristov et al. (2011) using analysis of variance showed that all sources of variation were highly significant for grain yield mean squares.

\subsection{Yield performance of the genotypes}

Means of grain yield of wheat cultivars averaged across two years and three locations are given in Table (3). The average grain yield performances of locations and years across varieties were different. Mean grain yield for the 6 environments ranged from 8.87 to 28.47 ( $\operatorname{ard} / \mathrm{fed}$.). Mean values in grain yields ranged from 16.87 to 28.47 (ard/fed.) and from 14.57 to 25.07 (ard/fed.) in Gemmieza location, from 10.07 to 17.40 (ard/fed.) and from 8.87 to 17.50 ( $\operatorname{ard} /$ fed.) in Nubaria location, and from 12.93 to 25.73 ( $\mathrm{ard} /$ fed.) and from 13.83 to 22.33 ( $\mathrm{ard} / \mathrm{fed}$.) in Mallawy location during 2008/2009 and 2009/2010 seasons, respectively. Grand mean grain yield of the genotypes was 21.11, 13.26 and 18.89 (ard/fed.) in Gemmieza, Nubaria and Mallawy regions, respectively. However, it was 18.71 and 16.79 (ard/fed.) during 2008/2009 and
2009/2010 seasons, respectively. There were a relatively large variation in grain yields, the variation in yields between genotypes was notably higher as compared to that between in locations and years. Values of environmental index varied between -4.75 to 4.87 in six environments, which were the highest for Gemmieza. Location Gemmieza gave the highest mean grain yield in both years, which has been the best environment for wheat production. Ülker et al. (2006) also found differences in grain yields of different wheat genotypes in response to different environmental conditions.

\subsection{Stability analysis}

\subsubsection{Analysis of variance}

Pooled analysis of variance also exhibited highly significant mean squares $(\mathrm{P}<0.01)$ due to the genotypes, environments and genotype $\times$ environment for grain yield (Table 4), revealing the presence of variability among genotypes as well as environments under which the experiments were conducted. The results of the combined analysis of stability are given in Table (5). An analysis of variance for stability revealed highly significant differences $(P<0.01)$ for grain yield among genotypes and environment $+(\mathrm{G} \times \mathrm{E})$. This reveals that not only the amount of variability existed among environments but also the presence of genetic variability among the genotypes. The sum of squares due to environments and genotype $\mathrm{x}$ environment are partitioned into environments (linear), genotype $\mathrm{x}$ environment (linear) and pooled deviation (nonlinear) from the regression model. The highly significance $(P<0.01)$ of these components showed that both predictable and unpredictable components shared GEI. The $\mathrm{G} \times \mathrm{E}$ (linear) interaction was highly significant (tested against pooled deviation) which demonstrated that genotypes respond differently to variation in environmental conditions and indicating existence 
Table (3): Means, ranges and values of environmental index (E.I.) of the various locations for grain yield (ard/fed.) of 40 wheat genotypes in Egypt during 2008/2009 - 2009/2010 seasons.

\begin{tabular}{|c|c|c|c|c|c|c|}
\hline Locations & \multicolumn{2}{|c|}{ Gemmieza } & \multicolumn{2}{|c|}{ Nubaria } & \multicolumn{2}{|c|}{ Mallawy } \\
\hline $\begin{array}{c}\text { Seasons } \\
\text { Genotypes }\end{array}$ & $2008 / 2009$ & $2009 / 2010$ & $2008 / 2009$ & $2009 / 2010$ & $2008 / 2009$ & $2009 / 2010$ \\
\hline Sakha 93 & 25.25 & 23.83 & 17.13 & 14.63 & 21.33 & 18.80 \\
\hline Sakha 94 & 26.03 & 20.40 & 16.33 & 14.10 & 23.48 & 19.47 \\
\hline Giza 168 & 22.77 & 21.37 & 13.70 & 14.67 & 21.55 & 20.03 \\
\hline Sids 1 & 19.40 & 18.60 & 13.73 & 12.87 & 25.73 & 22.33 \\
\hline Gemmieza 7 & 21.70 & 20.30 & 16.57 & 15.90 & 18.42 & 16.73 \\
\hline Gemmieza 9 & 28.47 & 24.83 & 12.87 & 13.30 & 20.88 & 19.73 \\
\hline Gemmieza 10 & 24.87 & 20.77 & 12.60 & 13.77 & 19.18 & 15.67 \\
\hline Promising 1 & 21.67 & 18.00 & 12.87 & 11.80 & 15.02 & 18.13 \\
\hline Promising 2 & 26.07 & 23.67 & 10.07 & 13.77 & 18.57 & 15.60 \\
\hline Promising 3 & 23.00 & 19.97 & 12.63 & 14.77 & 18.80 & 16.50 \\
\hline Promising 4 & 26.60 & 25.07 & 12.13 & 11.00 & 23.45 & 21.23 \\
\hline Promising 5 & 24.27 & 18.80 & 11.50 & 11.67 & 17.93 & 15.87 \\
\hline Promising 6 & 24.90 & 21.63 & 12.80 & 11.00 & 18.77 & 17.93 \\
\hline Promising 7 & 21.77 & 17.13 & 14.30 & 15.43 & 20.85 & 17.13 \\
\hline Promising 8 & 26.23 & 21.30 & 11.70 & 12.17 & 19.87 & 17.10 \\
\hline Promising 9 & 20.57 & 16.67 & 11.60 & 9.67 & 19.87 & 19.30 \\
\hline Promising 10 & 20.12 & 16.87 & 12.07 & 10.07 & 22.30 & 20.20 \\
\hline Promising 11 & 20.37 & 17.10 & 12.03 & 11.93 & 18.90 & 15.57 \\
\hline Promising 12 & 19.87 & 16.87 & 13.20 & 10.00 & 20.47 & 18.67 \\
\hline Promising 13 & 22.77 & 20.67 & 12.23 & 10.67 & 18.32 & 17.27 \\
\hline Promising 14 & 18.10 & 15.47 & 11.80 & 11.77 & 17.70 & 16.03 \\
\hline Promising 15 & 20.70 & 17.23 & 11.33 & 8.87 & 21.17 & 17.70 \\
\hline Promising 16 & 19.77 & 18.17 & 12.30 & 14.40 & 20.12 & 15.63 \\
\hline Promising 17 & 21.67 & 17.80 & 10.60 & 9.60 & 21.85 & 19.20 \\
\hline Promising 18 & 22.87 & 20.67 & 12.87 & 13.80 & 12.93 & 16.77 \\
\hline Promising 19 & 19.97 & 17.10 & 11.93 & 12.50 & 17.60 & 16.77 \\
\hline Promising 20 & 20.63 & 18.03 & 15.20 & 14.93 & 19.98 & 15.33 \\
\hline Promising 21 & 17.70 & 14.57 & 12.23 & 15.27 & 18.73 & 16.93 \\
\hline Promising 22 & 21.07 & 19.67 & 12.33 & 11.90 & 21.63 & 19.05 \\
\hline Promising 23 & 25.77 & 22.63 & 15.53 & 13.87 & 23.83 & 21.13 \\
\hline Promising 24 & 16.87 & 15.17 & 12.53 & 15.07 & 14.65 & 14.53 \\
\hline Promising 25 & 24.77 & 22.80 & 12.93 & 15.10 & 23.00 & 16.80 \\
\hline Promising 26 & 20.40 & 16.93 & 11.80 & 10.70 & 18.37 & 16.27 \\
\hline Promising 27 & 18.70 & 21.10 & 15.57 & 12.80 & 15.63 & 13.83 \\
\hline Promising 28 & 25.97 & 23.07 & 16.10 & 14.33 & 23.33 & 20.10 \\
\hline Promising 29 & 22.70 & 18.40 & 16.93 & 11.27 & 19.73 & 16.57 \\
\hline Promising 30 & 23.93 & 18.60 & 16.87 & 14.57 & 17.23 & 18.27 \\
\hline Promising 31 & 22.27 & 18.63 & 15.73 & 11.77 & 23.73 & 17.23 \\
\hline Promising 32 & 26.87 & 22.13 & 16.37 & 16.70 & 23.90 & 21.00 \\
\hline Promising 33 & 27.40 & 21.50 & 17.40 & 17.50 & 20.93 & 18.90 \\
\hline Mean & 22.62 & 19.59 & 13.51 & 13.00 & 19.99 & 17.78 \\
\hline Range & 11.60 & 10.50 & 7.33 & 8.63 & 12.80 & 8.50 \\
\hline E.I. & 4.87 & -4.24 & 2.25 & 1.84 & -4.75 & 0.03 \\
\hline
\end{tabular}




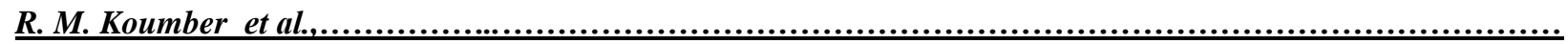

Table (4): Pooled analysis of variance of grain yield in 40 wheat genotypes grown in 6 locations in Egypt.

\begin{tabular}{|l|c|c|c|}
\hline \multicolumn{1}{|c|}{ S.O.V } & d.f & Mean squares & F \\
\hline Genotypes (G) & 39 & $49.17^{* *}$ & 16.52 \\
\hline Environments (E) & 5 & $1744.45^{* *}$ & 586.26 \\
\hline G x E & 195 & $11.88^{* *}$ & 3.99 \\
\hline Error & 480 & 2.98 & \\
\hline
\end{tabular}

$* *=$ Significant at $1 \%$ probability level.

Table (5). Stability analysis of grain yield of 40 wheat genotypes grown in 6 locations in Egypt.

\begin{tabular}{|l|c|c|}
\hline Source of variation & d.f & Mean squares \\
\hline Genotypes (G) & 39 & $16.39^{* *}$ \\
\hline Environment +(G X E) & 200 & $18.40^{* *}$ \\
\hline Environment (Linear) & 1 & $2907.42^{* *}$ \\
\hline G X E (linear) & 39 & $7.05^{* *}$ \\
\hline Pooled Deviation & 160 & $3.11^{* *}$ \\
\hline Pooled error & 480 & 0.99 \\
\hline
\end{tabular}

** = Significant at $1 \%$ probability level.

of differences among the regression coefficients. The pooled deviations were highly significant against pooled error, showing that the differences in stability were due to deviation from linear regression only. Further, the variation in stability of different cultivars performances was mainly due to genotypes by environment interaction. Afzal Arain et al. (2001) detected pooled analysis of variance overall environments, indicating that the genotype, environment and GEI mean squares were highly significant for grain yield. Therefore, an understanding of GEI provides valid insights into the selection of new stable genotypes in the diversified environmental conditions prevailing in a region. The mean squares due to $\mathrm{G} \times \mathrm{E}$ (linear) were non-significant, depicting lack of genetic differences among genotypes for linear response to varying environments, while the mean squares due to pooled deviations were highly significant, reflecting considerable differences among genotypes for non - linear response (Rasul et al., 2006).

Anwar et al. (2007) analyzed stability of variance for grain yield and reported highly significant variances due to environments and environment (linear), while non-significant variance was obtained for genotype. Genotypes, environments and GEI variances were significant at $\mathrm{P}<0.01$ (Akçura et al. 2009). Hristov et al. (2011) using the analysis of stability parameters denoted that the stability of grain yield per plant was existed.

\subsubsection{Stability parameters}

Calculated stability parameters for grain yield are presented in Table (6). Average grain yield, phenotypic variance $\left(\sigma_{\mathrm{P}}^{2}\right)$, coefficient of variation
(C.V. \%), regression coefficient $\left(b_{i}\right)$ and deviation from regression $\left(\mathrm{S}_{\mathrm{d}}^{2}\right)$ for the 40 genotypes ranged from 14.80 (promising line 24) to 21.16 (promising line 32), from 9.71 (promising line 24) to 225.49 (promising line 4), from 21.05 (promising line 24) to 75.57 (promising line 2), from 0.43 (promising line 21) to 1.72 (promising line 4 ) and from -0.74 (promising line 26) to 13.60 (Sids 1), respectively (Table 6). The large variation in mean grain yield, $\sigma_{P}^{2}$ C.V. $\%$, bi and $\mathrm{S}_{\mathrm{d}}{ }_{\mathrm{d}}$ indicated different responses of genotypes to environmental changes (Akçura et al., 2005). Grand mean of grain yield, $\sigma_{P}^{2}$ C.V. $\%, b_{i}$ and $S^{2}{ }_{d}$ were $17.75,91.98,52.07,1.00$ and 2.11, respectively. Nineteen genotypes in mean grain yield, $\sigma_{P}^{2}$ and C.V. $\%, 20$ genotypes in $b_{i}$ and 16 genotypes in $\mathrm{S}_{\mathrm{d}}^{2}$ gave higher values than the grand means for these corresponding stability parameters.

Genotype promising line 32, promising line 33, promising line 23, Sakha 93 and Gemmieza 9 had the highest grain yield across all locations. However, the genotype promising 24 gave the poorest performance across all the environments. The performance of all other genotypes was moderately well in all environments. According to Eberhart and Russell (1966), an ideal cultivar would have both a high average performance over a wide range of environments plus stability. The highest values of phenotypic variance across environments were recorded for promising line 4, Gemmieza 9 and promising line 2, although some genotypes with very close average yield had different phenotypic variances. This closer magnitude suggested that the greater role of variability is due to the environment conditions. 
Table (6): Estimates of stability and adaptability parameters of grain yield (ard/fed) for 40 bread wheat genotypes across 6 environments.

\begin{tabular}{|c|c|c|c|c|c|c|}
\hline No. & $\begin{array}{c}\text { Cultivars/ } \\
\text { Line }\end{array}$ & $\begin{array}{c}\text { Mean Grain } \\
\text { Yield } \\
\text { (ardab/feddan) }\end{array}$ & $\begin{array}{c}\text { Phenotypic } \\
\text { Variance } \\
\sigma_{P}^{2}\end{array}$ & $\begin{array}{c}\text { Coefficient } \\
\text { of } \\
\text { variation } \\
\text { C.V.\% } \\
\end{array}$ & $\begin{array}{c}\text { Regression } \\
\text { coefficient } \\
\left(b_{i}\right)\end{array}$ & $\begin{array}{c}\text { Deviation } \\
\text { from } \\
\text { regression } \\
\left(\mathbf{S}_{\mathrm{d}}^{2}\right) \\
\end{array}$ \\
\hline 1 & Sakha 93 & 20.16 & 82.33 & 45.00 & 1.01 & 1.15 \\
\hline 2 & Sakha 94 & 19.97 & 97.23 & 49.38 & 1.12 & 0.47 \\
\hline 3 & Giza 168 & 19.01 & 74.23 & 45.31 & 0.98 & -0.02 \\
\hline 4 & Sids 1 & 18.78 & 121.83 & 58.78 & 0.93 & 13.60 \\
\hline 5 & Gemmieza 7 & 18.27 & 26.79 & 28.33 & 0.54 & 0.42 \\
\hline 6 & Gemmieza 9 & 20.01 & 191.67 & 69.17 & 1.57 & 2.10 \\
\hline 7 & Gemmieza 10 & 17.81 & 108.51 & 58.49 & 1.16 & 1.80 \\
\hline 8 & Promising 1 & 16.25 & 68.72 & 51.02 & 0.86 & 2.80 \\
\hline 9 & Promising 2 & 17.96 & 184.11 & 75.57 & 1.44 & 7.38 \\
\hline 10 & Promising 3 & 17.61 & 70.11 & 47.54 & 0.93 & 0.71 \\
\hline 11 & Promising 4 & 19.91 & 225.49 & 75.41 & 1.72 & 1.33 \\
\hline 12 & Promising 5 & 16.67 & 116.25 & 64.67 & 1.23 & 0.57 \\
\hline 13 & Promising 6 & 17.84 & 137.29 & 65.68 & 1.34 & 0.76 \\
\hline 14 & Promising 7 & 17.77 & 43.77 & 37.23 & 0.70 & 1.01 \\
\hline 15 & Promising 8 & 18.06 & 156.67 & 69.30 & 1.44 & 0.44 \\
\hline 16 & Promising 9 & 16.28 & 106.15 & 63.29 & 1.11 & 2.98 \\
\hline 17 & Promising 10 & 16.94 & 120.45 & 64.80 & 1.11 & 6.67 \\
\hline 18 & Promising 11 & 15.98 & 61.15 & 48.92 & 0.91 & -0.65 \\
\hline 19 & Promising 12 & 16.51 & 85.04 & 55.85 & 0.98 & 2.97 \\
\hline 20 & Promising 13 & 16.99 & 111.33 & 62.12 & 1.21 & 0.15 \\
\hline 21 & Promising 14 & 15.14 & 38.75 & 41.11 & 0.70 & -0.24 \\
\hline 22 & Promising 15 & 16.17 & 125.69 & 69.35 & 1.24 & 2.27 \\
\hline 23 & Promising 16 & 16.73 & 49.01 & 41.84 & 0.75 & 0.92 \\
\hline 24 & Promising 17 & 16.79 & 146.23 & 72.04 & 1.34 & 2.90 \\
\hline 25 & Promising 18 & 16.65 & 91.04 & 57.31 & 0.81 & 9.84 \\
\hline 26 & Promising 19 & 15.98 & 48.88 & 43.76 & 0.81 & -0.68 \\
\hline 27 & Promising 20 & 17.35 & 32.71 & 32.96 & 0.60 & 0.62 \\
\hline 28 & Promising 21 & 15.91 & 27.96 & 33.24 & 0.43 & 2.64 \\
\hline 29 & Promising 22 & 17.61 & 94.89 & 55.32 & 1.09 & 1.16 \\
\hline 30 & Promising 23 & 20.46 & 112.46 & 51.83 & 1.23 & -0.52 \\
\hline 31 & Promising 24 & 14.80 & 9.71 & 21.05 & 0.26 & 0.23 \\
\hline 32 & Promising 25 & 19.23 & 120.22 & 57.01 & 1.21 & 2.29 \\
\hline 33 & Promising 26 & 15.74 & 71.24 & 53.61 & 0.98 & -0.74 \\
\hline 34 & Promising 27 & 16.27 & 48.11 & 42.63 & 0.53 & 5.89 \\
\hline 35 & Promising 28 & 20.48 & 102.05 & 49.32 & 1.18 & -0.71 \\
\hline 36 & Promising 29 & 17.60 & 72.82 & 48.49 & 0.88 & 3.13 \\
\hline 37 & Promising 30 & 18.24 & 48.94 & 38.34 & 0.68 & 2.85 \\
\hline 38 & Promising 31 & 18.23 & 95.75 & 53.68 & 1.02 & 4.10 \\
\hline 39 & Promising 32 & 21.16 & 83.91 & 43.29 & 1.06 & -0.53 \\
\hline 40 & Promising 33 & 20.61 & 69.90 & 40.57 & 0.88 & 2.50 \\
\hline & Mean & 17.75 & 91.98 & 52.07 & 1.00 & 2.11 \\
\hline
\end{tabular}

Promising lines 2, 4 and 17 differed from the other genotypes by higher C.V. \% values, but the promising line 24 and Gemmieza 7 had lower C.V. \%. Ortiz et al. (2001) suggested that it may be possible to select simultaneously for high and stable grain yield by selecting outyielders that exhibit a low C.V. \%.

The coefficient of variation for the dough stability time ranged from 24.29 to $49.60 \%$ across different varieties, locations, and years (Ji-Chun et 
al., 2007). Mustãţea1 et al., (2009) stated that, plotting C.V.'s against average yield proved to be the most useful tool in identifying cultivars with high and stable yield.

The variations in regression coefficient $\left(b_{i}\right)$ values suggested that the forty genotypes responded differently to the different environments. Variability among environments is an important factor and mostly determines the usefulness of b values (Ülker et al., 2006).

The regression coefficient $\left(b_{i}\right)$ values of the forty genotypes used in this study exhibited no genotype with $b$-values equal to 1.00 . The regression coefficient values of Sakha 93, promising lines 31, 32, 12 and Giza 168 genotypes were close to unity. Hence, these genotypes may be considered as stable genotypes. Twenty out of forty genotypes had regression coefficients above unity, while other genotypes expressed b values below unity. Regression values above 1.00 describe genotypes with higher sensitivity to environmental change (below average stability) and greater specificity of adaptability to high yielding environments. Promising line 32, promising line 33, promising line 23, Sakha 93 and Gemmieza 9 had regression coefficient values of $1.06,0.88,1.23,1.01$ and 1.57 , respectively, with high grain yield (Table 6).

Promising line 4 had the highest (1.72) regression coefficient, followed by Gemmieza 9 (1.57), promising line 2 (1.44) and promising line 8 (1.44). The yields of these lines were significantly affected by varying environmental conditions and yields increased when the conditions were adequate and decreased to below average when the conditions were inadequate.

Baker (1988) considered deviation from regression $\left(\mathrm{S}_{\mathrm{d}}^{2}\right)$ to be the most appropriate criterion for measuring phenotypic stability in an agronomic sense, because this parameter measures the predictability of genotypic reaction to environment; with high and desirable per se performance of a variety across environments is also a positive point to rate the variety as a better and highly stable genotype. The genotypes displayed a wide range of values for $\mathrm{S}_{\mathrm{d}}{ }_{\text {f }}$ for grain yield. The genotypes; promising line 13, promising line 24, Gemmieza 7 and Giza 168 gave low $S_{d}^{2}$ values which show better stability and specific adaptation to favourable environments. Five genotypes; Sids 1, promising line 18 , promising line 2 , promising line 10 and promising line 27 had high $\mathrm{S}_{\mathrm{d}}{ }_{\mathrm{d}}$, indicating less stability and indicating sensitivity to environmental changes. Due to the high values of
$\mathrm{S}_{\mathrm{d}}^{2}$, these genotypes are expected to give good yield under favorable environmental conditions. Deviation from regression as small as possible is the measure of genotypic stability across a set of environments (Abdul Majid et al., 2007).

Accordingly, the promising line $32(\bar{x}=21.16$, $b_{i}=1.06$ and $\left.S_{d}^{2}=-0.53\right)$, Sakha $93\left(x=20.16, b_{i}\right.$ $=1.01$ and $\left.\mathrm{S}_{\mathrm{d}}{ }_{\mathrm{d}}=1.15\right)$ and Giza $168\left(\bar{x}=19.01, \mathrm{~b}_{\mathrm{i}}\right.$ $=0.98$ and $\mathrm{S}_{\mathrm{d}}^{2}=-0.02$ ) were the most stable for grain yield because their regression coefficients were the highest, $b_{i}$ value almost near unity and they had lower deviations from regression; these would be recommended for environmental conditions of Gemmieza, Nubaria and Mallawy locations. Genotypes with high mean yield, a regression coefficient equal to the unity $\left(b_{i}=1\right)$ and small deviations from regression $\left(\mathrm{S}_{\mathrm{d}}^{2}=0\right)$ are considered stable (Finlay and Wilkinson, 1963; Eberhart and Russell, 1966). Parveen et al. (2010) noticed some cultivars as stable on the basis of overall mean yields and stability parameters viz., regression coefficients and minimum deviations from regression. Özgen (1994), Ülker et al. (2006), Abdul Majid et al. (2007), Akçura et al. (2009), Feiziasl, et al. (2010) and Hristov et al. (2011) considered that a desirable genotype with stability and above average grain yield should have a regression line with a positive intercept and slope equal to 1.0 and lower deviation from regression.

\subsubsection{Correlations}

The correlation coefficients among the mean grain yield and stability parameters are presented in Table (7). The regression coefficient $\left(b_{i}\right)$ displayed highly significantly positive correlation with mean grain yield $(0.45)$, phenotypic variance $(0.95)$ and coefficient of variation (0.90). Moreover, the phenotypic variance displayed significant and highly significant positive correlation with mean grain yield $(0.40)$ and coefficient of variation (0.92), respectively. In contrast, the deviations from regression demonstrated insignificant correlation with mean grain yield (-.06), phenotypic variance (0.23), coefficient of variation (0.28) and regression coefficient (-0.02). Despite existence of several highly significant correlations, it is obvious that each stability parameter and especially those belonging to different groups according to Lin et al. (1986) and Mustãţeal et al. (2009) describe different aspects of genotypes $\mathrm{x}$ environment interaction. Hugo Ferney et al. (2006) mentioned that grain yield correlated significantly and 
Table (7): Correlation coefficients between mean yield and the studied stability parameters.

\begin{tabular}{|l|c|c|c|c|c|}
\hline Stability parameters & Mean & $\boldsymbol{\sigma}_{\mathbf{P}}^{2}$ & $\mathbf{C . V . \%}$ & $\mathbf{b}_{\mathbf{i}}$ & $\mathbf{S}_{\mathbf{d}}^{\mathbf{2}}$ \\
\hline Mean & 1.00 & $0.40^{*}$ & 0.11 & $0.45^{* *}$ & -0.06 \\
\hline $\boldsymbol{\sigma}_{\mathbf{P}}^{2}$ & & 1.00 & $0.92^{* *}$ & $0.95^{* *}$ & 0.23 \\
\hline $\mathbf{C . V . \%}$ & & & 1.00 & $0.90^{* *}$ & 0.28 \\
\hline $\mathbf{b}_{\mathbf{i}}$ & & & & 1.00 & -0.02 \\
\hline $\mathbf{S}_{\mathbf{d}}^{\mathbf{2}}$ & & & & & 1.00 \\
\hline
\end{tabular}

positively with the stability parameters regression coefficient and deviation from regression. Phenotypic variance and coefficient of variation were significantly correlated with average grain yield regression coefficient and deviation from regression (Mustãţea1 et al., 2009).

\section{REFERENCES}

Abdul Majid S., Asghar, R. and Murtaza, G. (2007). Yield stability analysis conferring adaptation of wheat to pre- and post-anthesis drought conditions. Pak. J. Bot., 39(5): 1623 $-1637$.

Afzal Arain M., Sial M.A. and Javed M.A. (2001). Stability analysis of wheat genotypes tested in multi-environmental trail (METs) in Sindh Province. Pak. J. Bot., 33: 761 - 765.

Akçura M., Kaya Y. and Taner S. (2005). Genotype-environment interaction and phenotypic stability analysis for grain yield of durum wheat in the Central Anatolian Region. Turk. J Agric., 29: 369 - 375.

Akçura M., Kaya Y. and Taner S. (2009). Evaluation of durum wheat genotypes using parametric and nonparametric stability statistics. Turk. J. of Field Crops, 14(2): 111 $-122$.

Allard R.W. and Bradshaw A.D. (1964). Implications of genotype environmental interactions in applied plant breeding. Crop Sci., 4: 503 - 507.

Anwar J., Khan S.B., Rasul I., Zulkiffal M. and Hussain M. (2007). Effect of sowing dates on yield and yield components in wheat using stability analysis. Inter. J. of Agric. and Biol., 1: 129-132.

Baker R.J. (1988). Test for crossover genotypeenvironmental interaction. Canadian J. Pl. Sci., 68: 405-10

Björnsson I. (2002). Stability analysis towards understanding genotype $\mathrm{x}$ environment interaction. Plant Agriculture Department of University of Guelph,Ontario, Canada. www.genfys.slue.se/staff/deg/nova02.

Carvalho F.I.F., Federizzi L.C. and Nodari R.O. (1983). Comparison among stability models in evaluating genotypes. Rev. Bras. Genet., 6(4): $667-691$.

Comstock R.E. and Moll R.H. (1963). Genotypeenvironment interactions. In: Statistical Genetics and Plant Breeding, (Ed: W.D. Hanson and H.F. Robinson). Proc. Natl. Acad. Sci.-NRC Pub. no. 982, pp. $164-196$.

Eberhart S.A. and Russell W.A. (1966). Stability parameters for comparing varieties. Crop Sci., 6: 36-40.

Feiziasl V., Jafarzadeh J. Amri A., Ansari Y., Mousavi S.B. and Chenar M.A. (2010). Analysis of yield stability of wheat genotypes using new crop properties balance index (cpbi) method. Notulae Botanicae Horti Agrobotanici Cluj-Napoca, 38(1), 228 - 233.

Finlay W. and Wilkinson G.N.R. (1963). The analysis of adaptation in a plant breeding programme. Aust. J. Ag. Res., 14: 742-754.

Fisher, R.A and Yates, F. (1953). Statistical Tables for Biological, Agricultural, and Medical Research. Olive and Boyd, Edinbugh, p.94.

Hristov N., Mladenov N., Kondic-Špika A., Marjanovic-Jeromela A., Jockovic B. and Jacimovic G. (2011). Effect of environmental and genetic factors on the correlation and stability of grain yield components in wheat. Genetika, 43(1): 141-152.

Hugo Ferney G.B., Alexei M. and Aigul A. (2006). Evaluation of grain yield stability, reliability and cultivar recommendations in spring wheat (Triticum aestivum L.) from Kazakhstan and Siberia. J. of Central European Agric., 7(4): 649 - 659.

Ji-Chun T., Rui-Bo H.U., Zhi-Ying D. and YanXun W. (2007). The variation and stability analysis of wheat dough stability time. Agric. Sci., in China, 6(2): 143-149.

Khan A.G., Ali A., Azam F.I. and Tariq M. (2007). Grain yield stability analysis of wheat genotypes from NWFP of Pakistan. Pakistan J. Agric. Res., 20(3-4): 105 - 109.

Lin C.S., Binns M.R. and Lefkovitch L.P. (1986). Stability analysis: Where do we stand. Crop Sci. 26: 894-900. 
Moldovan V., Moldovan M. and Kadar R. (2000). Item from Romania. S.C.A. Agricultural Research Station. Turda, 3350, str. Agriculturii 27 Jud Chuj, Romania.

Mustãţea1 P., Saulescu N.N., Ittu1 G., Paunescu G.,Voinea L., Stere I., Mîrlogeanu S., Constantinescu E. and Nastase D. (2009). Grain yield and yield stability of winter wheat cultivars in contrasting weather conditions. Romanian Agric. Res. 26: $1-8$.

Ortiz R., Wagoire W. W., Hill J., Chandra S., Madsen S. and Stølen O. (2001). Heritability of and correlations among genotype-byenvironment stability statistics for grain yield in bread wheat. Theor. Appl. Genet., 103: $469-474$.

Özgen M. (1994). Analysis of adaptation and stability in yield and yield component of winter barley under Central Anatolia conditions. Turkish J. of Agric. and Forestry, 18: $169-177$.
Parveen L., Khalil I.H. and Khalil S.K. (2010). Stability parameters for tillers, grain weight and yield of wheat cultivars in north-west of Pakistan. Pak. J. Bot., 42(3): 1613 - 1617.

Rasul I., Zulkiffal M., Anwar J., Khan S.B., Hussain M. and Riaz U.D. (2006). Grain yield stability of wheat genotypes under different environments in Punjab. J. of Agric. and Soc. Sci., 4:222-224.

Shindin I.M. and Lokteva O.V. (2000). Evaluation of spring wheat varieties at Primorskey for ecological plasticity. Ann. Wheat. Newslet., 46: 105 - 106.

Stafford R.E. (1982). Yield stability of guar breeding lines and cultivars. Crop. Sci., 2(5): $1009-1011$.

Ülker M., Sönmez F., Çiftçi V., Yilmaz N. and Apak R. (2006). Adaptation and stability analysis in the selected lines of tir wheat. Pak. J. Bot., 38(4): 1177-1183.

$$
\begin{aligned}
& \text { تحليل الثبات والتفاعل التركيب x البيئة لمحصول الحبوب في قمح الخبز } \\
& \text { رضا محمد قمبر- عصام فتحى الحشاث** ـ صبرى أحمد سليم } \\
& \text { قسم بحوث القمح - معهد بحوث المحاصيل الحقليةـ مركز البحوث الزر اعية. } \\
& \text { *ققم المحاصيل _ كلية الزر اعة - جامعة الأز هر ـ القاهرة - مصر. }
\end{aligned}
$$

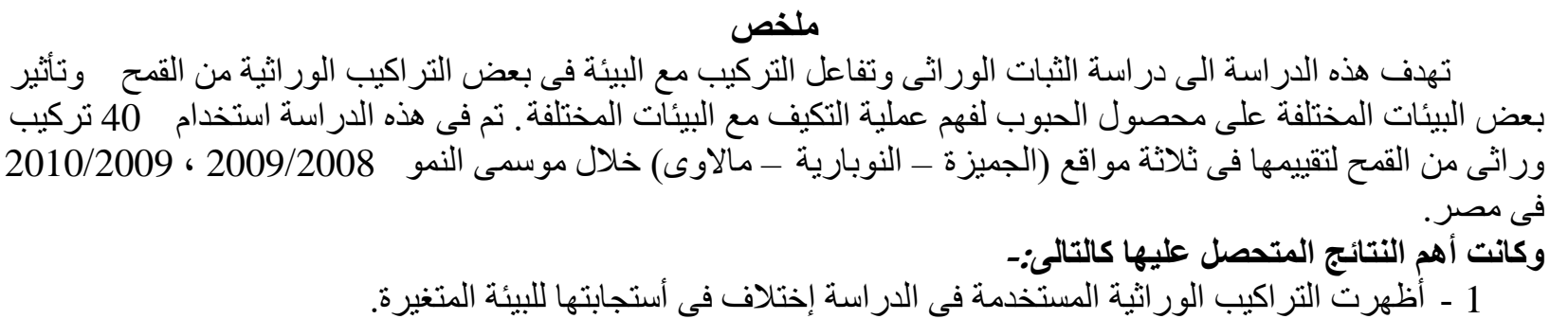

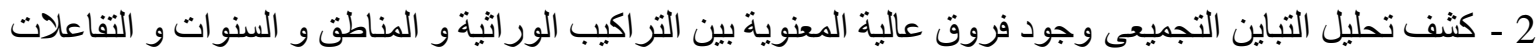

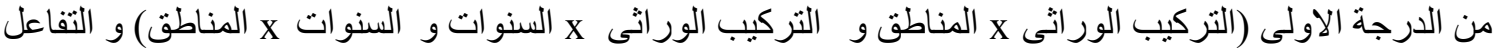

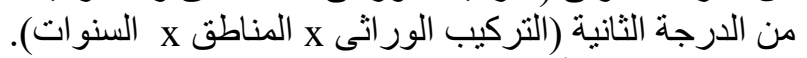

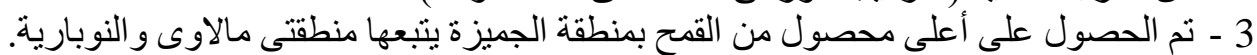

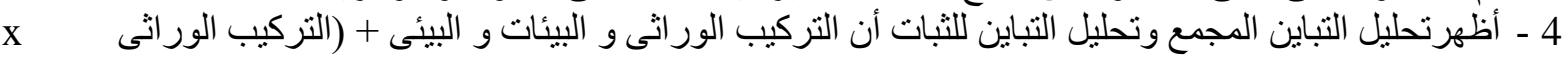

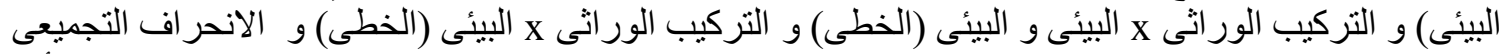

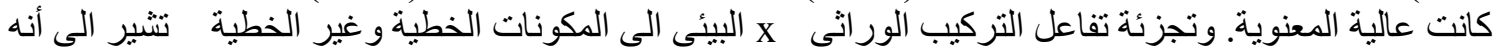

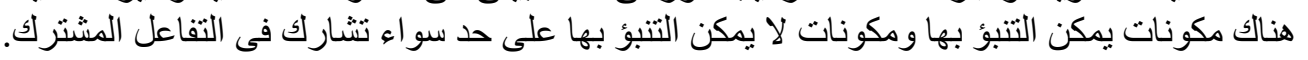
5 - كما لوحظ وجود مدى و اسع للثبات بين التر اكيب الور الثئ التئ لكل مقاييس الثبات.

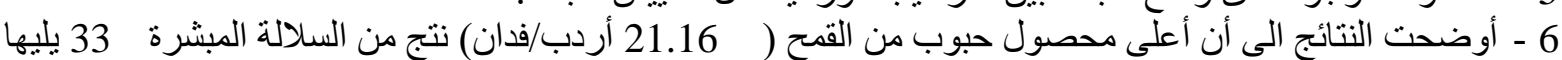
المبشرة 34 و المبشرة 29 و المبر المبشرة 24 و و سخا 93 و 93 و جميزة 10.

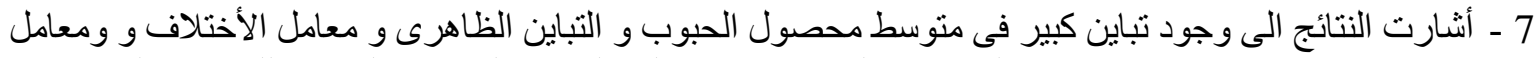

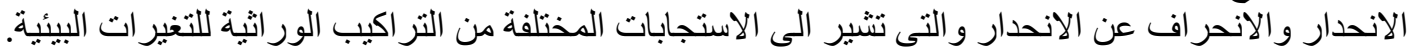


8 ـ أظهرت التر اكيب الور اثية سخا 93 و المبشرة 24 و المبشرة 32 و المبشرة 33 محصول حبوب عالى و انحر اف باف

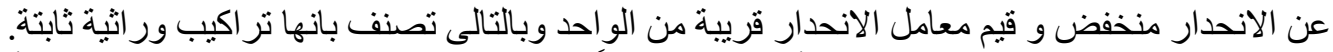

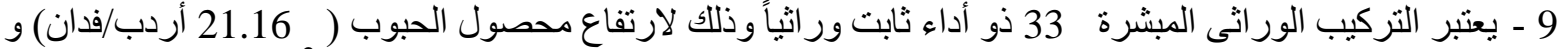

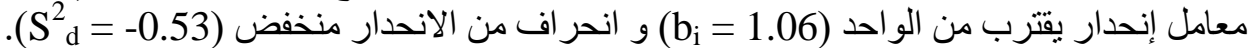

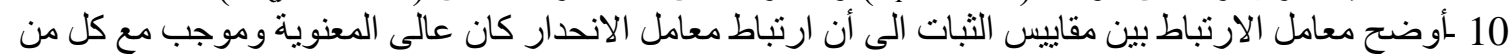

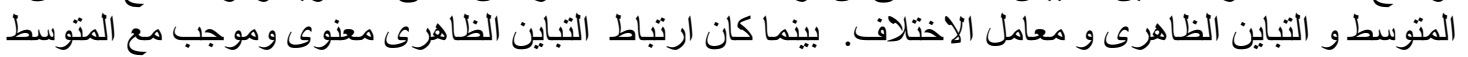

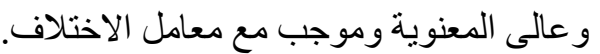

المجلة العلمية لكلية الزراعة - جامعة القاهرة - المجلد (62) العدد الرابع (أكتوبر 2011): 457-467. 